\title{
Effect of fatty acids on the $\beta$-oxidation system and thioesterase of Lactococcus lactis subspecies lactis
}

\author{
Liang $\mathrm{Li}^{*} \dagger$ and Ying $\mathrm{Ma}^{* 1}$ \\ *School of Food Science and Engineering, Harbin Institute of Technology, 202 Haihe Road, Harbin, Heilongjiang 150090, China \\ †College of Food Science, Northeast Agricultural University, 59 Gongbin Road, Harbin, Heilongjiang 150030, China
}

\begin{abstract}
The influence of fatty acids on the $\beta$-oxidation system and thioesterase of Lactococcus lactis was investigated in this study. The results showed that fatty acids (C8:0-C16:0) significantly inhibited the growth of Lactococcus lactis, and laurate (C12:0) had the highest bactericidal effects. We detected the maximum activity of $\beta$-oxidation at different incubation times $(8,12$, and $18 \mathrm{~h}$ ) to be $6.460,7.751$, and 8.203 , respectively, and the maximum activity of thioesterase at different incubation times $(8,12$, and $18 \mathrm{~h})$ to be $19.498,27.180$, and 12.800 , respectively. Fatty acids were seen to induce the $\beta$-oxidation system and activity of thioesterase; decanoic acid (C10:0) and palmitic acid (C16:0) were also seen to induce the $\beta$-oxidation system of Lactococcus lactis, but the induced ability was significantly different. Octanoic acid (C8:0) and palmitic acid (C16:0) were seen to induce thioesterase activity in Lactococcus lactis. When $1 \mathrm{~m} M$ palmitic acid (C16:0) was added to M17 broth, the activity of thioesterase increased 5 -fold after 2 min; however, adding octanoic acid (C8:0) changed the activity little. Evidence showed that the ability to induce the $\beta$-oxidation system and thioesterase activity was related to the fatty acids' chain lengths.
\end{abstract}

Key words: fatty acid, $\beta$-oxidation system, thioesterase, Lactococcus lactis ssp. lactis

\section{INTRODUCTION}

Free fatty acids released as a result of milk fat lipolysis are important flavors in food, but they must be counter-balanced with other flavor compounds to develop a pleasing aroma (Bosset and Gauch, 1993; Fox et al., 1995). Free fatty acids are substrates of enzymatic reactions yielding flavors (Marilley, 2004) and can be metabolized to produce many flavor compounds, such as methyl ketones, lactones, esters, and secondary alcohols (Fox and Wallace, 1997).

Received July 30, 2012.

Accepted December 27, 2012.

${ }^{1}$ Corresponding author: maying@hit.edu.cn
Methyl ketones are important flavor compounds, particularly in cheese (Urbach, 1997). In cheese made from pasteurized milk, lactic acid bacteria are a major source of lipolytic enzymes (Boumerdassi et al., 1997). Cheese made with a starter system containing a blend of 2 commercial Lactococcus lactis strains with the highest levels of 2-pentanone and 2-heptanone highlighted the effect of starter Lc. lactis on methyl ketones (Hannon et al., 2007). Therefore, Lc. lactis has a positive effect on methyl ketones in most dairy products.

Methyl ketones are formed from incomplete $\beta$-oxidation; the steps include $\beta$-oxidation of the released FFA to $\beta$-ketoacyl-CoA, which are then deacylated into $\beta$-ketoacids under the action of the thioesterases, and then the keto acids are decarboxylated to methyl ketones (Engelvin et al., 2000; Town et al., 2000). Many studies have researched the $\beta$-oxidation of fungi such as Aspergillus niger (Baltazar et al., 1999), Penicillium roqueforti (Chalier and Crouzet, 1998), Sporidiobolus spp. (Feron et al., 2005), and Yarrowia lipolytica (Groguenin, 2004). Studies on bacteria were less frequent, however, with research available for strains such as Staphylococcus carnosus (Engelvin et al., 2000; Groguenin, 2004) and Caulobacter crescentus (O'Connell, 1986); no information about Lc. lactis was found, however. Lactococcus lactis is widely used in food industry for production of fermented milk products (Sirén et al., 2009) such as fresh and semi-hard cheeses and sour milks (Samaržija et al., 2001). Therefore, it is very important to study the role of Lc. lactis in the production of methyl ketones.

In the present study, we attempted to prove that Lc. lactis had the ability to generate methyl ketone by measuring $\beta$-oxidation capacity and thioesterase activity; this process could be induced by FFA of different chain lengths. The results of this research will provide a pre-theoretical basis for the future regulation of a $L c$. lactis-methyl ketone generation system.

\section{MATERIALS AND METHODS}

\section{Chemicals and Culture Media}

Coenzyme A (CoA; trilithium salt) and palmitoylCoA were purchased from Sigma Chemical Co. 
(Shanghai, China); 5,5'-dithio-bis(2-nitrobenzoic acid; DNTB), HEPES, phenylmethylsulfonyl fluoride (PMSF), EDTA, and $\mathrm{NAD}^{+}$were purchased from Aladdin Chemistry Co. (Shanghai, China). Enhanced bicinchoninic acid (BCA) Protein Assay Kit was purchased from Beyotime Institute of Biotechnology (Jiangsu, China).

\section{Microorganism}

Lactococcus lactis ssp. lactis was grown in M17 broth medium (Hope Bio-Technology Co., Qingdao, China) at $37^{\circ} \mathrm{C}$. Cell density was measured by using a spectrophotometer (TU-1800 Pgeneral Instrument Co. Ltd., Beijing, China) at $600 \mathrm{~nm}$.

\section{Volatile Compounds Analysis}

Cream was obtained from unpasteurized bovine milk by centrifuging at $6,500 \times g$. Pasteurized cream was fermented by Lactococcus lactis ssp. lactis at $37^{\circ} \mathrm{C}$ and considered as fermented cream. Twenty grams of fermented cream was placed in a $100-\mathrm{mL}$ vial and exposed to the headspace for $90 \mathrm{~min}$ at $70^{\circ} \mathrm{C}$. All extractions were carried out using a solid-phase extraction (SPME) fiber (Supelco, Bellefonte, PA). The trapped compounds were injected onto the column of an HP 5890 Gas Chromatograph (Hewlett-Packard, Palo Alto, CA) equipped with DB-5 capillary column $(60 \mathrm{~m} \times 0.25 \mathrm{~mm}$ $\times 0.25 \mathrm{~mm}$ film thickness). Volatile compounds were separated under the following conditions: carrier gas was helium at $1 \mathrm{~mL} / \mathrm{min}$, and initial temperature was $60^{\circ} \mathrm{C}$ held for $3 \mathrm{~min}$, heated to $150^{\circ} \mathrm{C}$ at $6^{\circ} \mathrm{C} / \mathrm{min}$, followed by heating to $230^{\circ} \mathrm{C}$ at $4^{\circ} \mathrm{C} / \mathrm{min}$. The $\mathrm{GC}$ column was connected without splitting to the ion source of a mass spectrometer. Ionization was performed by electron impact at $70 \mathrm{eV}$. Quantification was performed by integrating the peak areas of total ion chromatograms by the GC-MS software.

\section{FFA as Growth Factors on Lc. lactis}

Hexanoic acid (C6:0), octanoic acid (C8:0), decanoic acid (C10:0), lauric acid (C12:0), myristic acid (C14:0), and palmitic acid (C16:0; purity 97\%, Aladdin Chemistry Co.) were used as FFA supplements in M17 broth media for growth tests; FA stock solutions $(0.25 \mathrm{M})$ were made in absolute ethanol and further sterilized by membrane filtration $(0.22 \mu \mathrm{m})$. Fatty acid stock solutions were added to the fresh sterile M17 medium to a final amount of $1 \mathrm{~m} M$. After addition of inoculum $(4.0 \% \mathrm{vol} / \mathrm{vol})$, culture was mixed and incubated at $37^{\circ} \mathrm{C}$. Growth tests were performed as optical density value by a spectrophotometer (TU-1800 General Instrument Co. Ltd.) at $600 \mathrm{~nm}$.

\section{Preparation of Cell-Free Extracts}

Cell-free extracts (CFE) were performed as described by Engelvin et al. (2000) with modifications. Cells were harvested at 5,000 $\times g$ for $10 \mathrm{~min}$ at $4^{\circ} \mathrm{C}$, washed with $\mathrm{K}_{2} \mathrm{HPO}_{4} / \mathrm{KH}_{2} \mathrm{PO}_{4}(100 \mathrm{mM}, \mathrm{pH} 7.5)$, and sonicated in HEPES buffer (20 mM, pH 7.5) containing $1 \mathrm{~m} M$ EDTA and $1 \mathrm{~m} M$ PMSF using a JY92-II (Ningbo Scientz Biotechnology Co. Ltd., Ningbo, China) ultrasonic homogenizer (30 cycles of $10 \mathrm{~s}$ on and $10 \mathrm{~s}$ off at 300 $\mathrm{W})$. Unbroken bacteria were removed by centrifugation at $5,000 \times g$ for $10 \mathrm{~min}$ at $4^{\circ} \mathrm{C}$. The supernatant fraction was designated crude $\mathrm{CFE}$ and was used immediately or stored at $-80^{\circ} \mathrm{C}$. The amount of protein in the $\mathrm{CFE}$ was determined by Enhanced BCA Protein Assay Kit.

\section{$\beta$-Oxidation Assays}

Assay of $\beta$-oxidation was completed by measuring the 3-hydroxyacyl-CoA dehydrogenase (EC 1.1.1.35) activity, which was determined using acyl-CoA as substrate. The assay mixture contained $72 \mathrm{nmol}$ of $\mathrm{CoA}$, $1.7 \mu \mathrm{mol}$ of $\mathrm{NAD}^{+}, 72 \mathrm{nmol}$ of palmitoyl-CoA, $280 \mu \mathrm{g}$ of CFE protein, and $\mathrm{K}_{2} \mathrm{HPO}_{4} / \mathrm{KH}_{2} \mathrm{PO}_{4}(300 \mathrm{~m} M$, pH 8.0) in a final volume of $1 \mathrm{~mL}$. The reduction of NAD was measured by its absorption at $340 \mathrm{~nm}$ against a control sample without substrates. The $\beta$-oxidation activity was expressed as nanomoles of $\mathrm{NAD}^{+}$reduced per milligram of protein per minute $\left[\varepsilon_{\mathrm{NAD}}(340)=6,220\right.$ $M^{-1} \mathrm{~cm}^{-1}$; Engelvin et al., 2000].

\section{Thioesterase Activity}

Thioesterase activity (EC 3.1.2.2) was measured by the release of coenzyme A (CoASH), which was assayed continuously by its reaction with DTNB. The assay contained, in a final volume of $1 \mathrm{~mL}, \mathrm{~K}_{2} \mathrm{HPO}_{4} / \mathrm{KH}_{2} \mathrm{PO}_{4}$ (300 mM, pH 8.0), $250 \mathrm{nmol}$ of DTNB, $72 \mathrm{nmol}$ of palmitoyl-CoA, and $280 \mu \mathrm{g}$ of CFE protein. Activity was measured by following the increase in absorbance at 412 $\mathrm{nm}$ against a control without substrates $\left[\varepsilon_{\text {DTNB }}(412)=\right.$ $13,600 \mathrm{M}^{-1} \mathrm{~cm}^{-1}$. Activity was expressed as nanomoles of palmitoyl-CoA deacylated per milligram of protein per minute (Engelvin et al., 2000).

\section{Statistical Analysis}

All statistical treatments were carried out using the SPSS program for Windows (SPSS 17.0, SPSS Inc., Chicago, IL). 


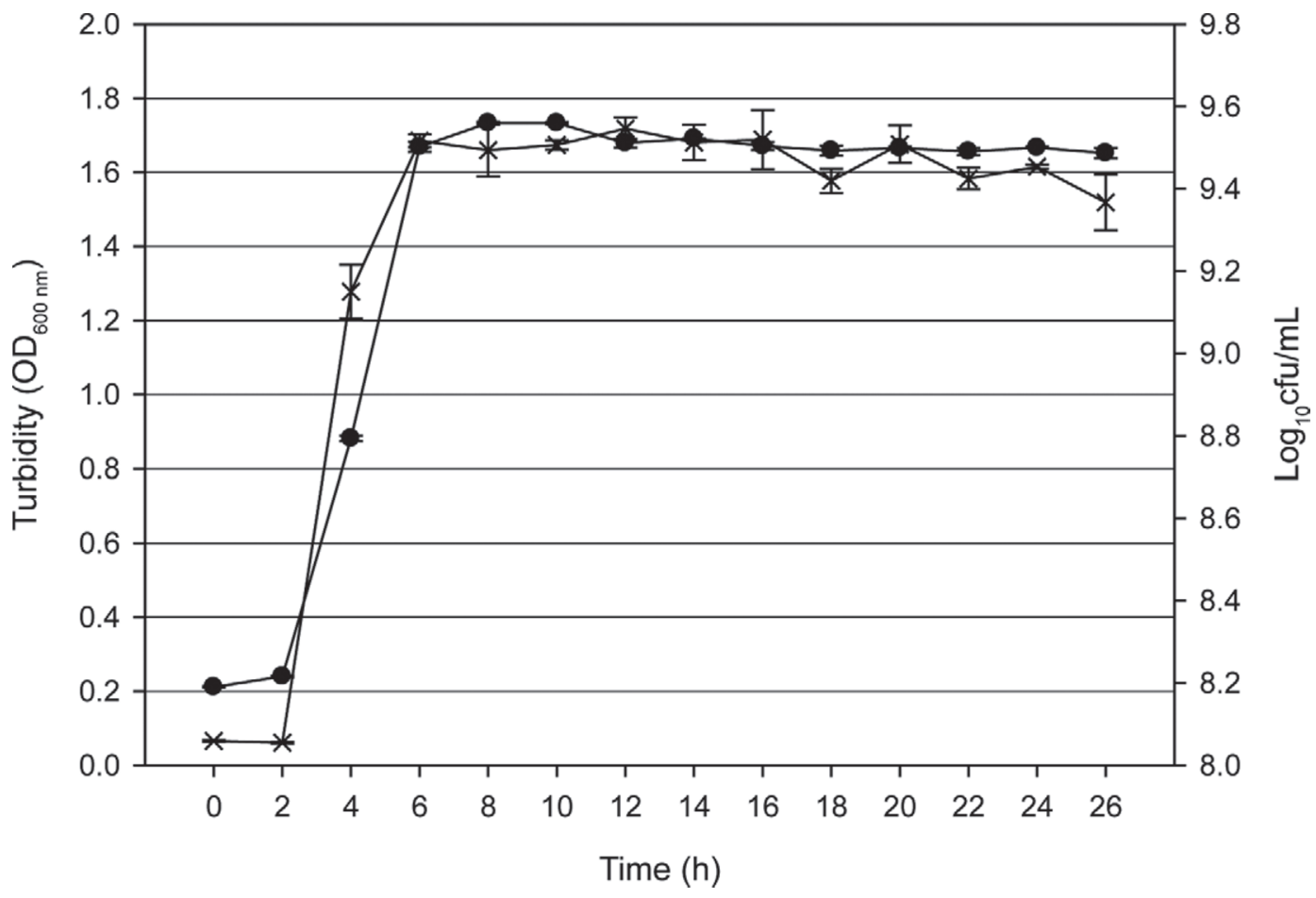

Figure 1. Growth curve of Lactococcus lactis for cells incubated at different times. Optical density (OD) at $600 \mathrm{~nm}$ value $(\bullet), \log _{10} \mathrm{cfu} / \mathrm{mL}$ value $(\times)$.

\section{RESULTS AND DISCUSSION}

\section{Growth Curve of Lc. lactis ssp. lactis}

Figure 1 indicates the growth curve of Lc. lactis on M17 medium at different incubation times. As shown in Figure 1, the lag phase was from 0 to $2 \mathrm{~h}$, exponential phase was from 2 to $8 \mathrm{~h}$, and stationary phase was from 8 to $24 \mathrm{~h}$. This was similar to earlier findings for Lc. lactis UQ2 growing in supplemented whey, which entered the stationary phase after $8 \mathrm{~h}$. In contrast, growth of Lc. lactis UQ2 in skim milk showed the beginning of the stationary phase after $6 \mathrm{~h}$ (García-Parra et al., 2011). Growth of Lc. lactis ssp. lactis ATCC 29146 and Lc. lactis IPLA 947 showed the beginning of the stationary phase after 12 h (Cárcoba et al., 2000; Valbuena et al., 2005). Cells of Lc. lactis ssp. lactis ATCC11454 entered the stationary phase after 5 or 10 h (Liu et al., 2005; Nagayasu et al., 2007). The different behaviors of growth characteristics could be caused by differences of species, broth medium nutrients, or incubation time.

Growth data of the bacteria Lc. lactis could be tracked by viable cell counts, optical density, and acidification rate (Ayala-Hernández et al., 2008). Optical density showed not only living bacterial biomass, which were able to multiply, but also partially autolysed or dead biomass; cell count method showed only viable cells (Kabanova et al., 2009). Growth curve measured by optical density was in agreement with the results of cell counts measured, indicating that optical density could be used for the study of the bacterial growth in this experiment (Figure 1). According to the growth curve, this paper assayed the $\beta$-oxidation and thioesterase activity of Lc. lactis on incubation time at 8 $\mathrm{h}$ (late-exponential), $12 \mathrm{~h}$ (early-stationary), and $18 \mathrm{~h}$ (late-stationary phase).

\section{Assessment of Volatile Compounds}

Methyl ketones have typical odors and low perception thresholds (Curioni and Bosset, 2002). These ketones are important in the aroma compounds of most dairy products: 2-heptanone has a musty, sweet, moldy, varnish odor; 2-nonanone has a floral, fruity, peach odor (Frank, 2003); 2-undecanone has floral and musty notes (Delgado, 2011); and 2-tridecanone has a goat-like odor (Curioni and Bosset, 2002). Compared with cream, fermented cream made with Lc. lactis ssp. lactis had higher levels of 2-heptanone, 2-nonanone, 2 -undecanone, and 2-tridecanone (Table 1 ). The results highlight the positive effect of Lc. lactis ssp. lactis on methyl ketones. Thus, Lc. lactis ssp. lactis may have the capacity to synthesize these compounds related to the $\beta$-oxidation pathway. 


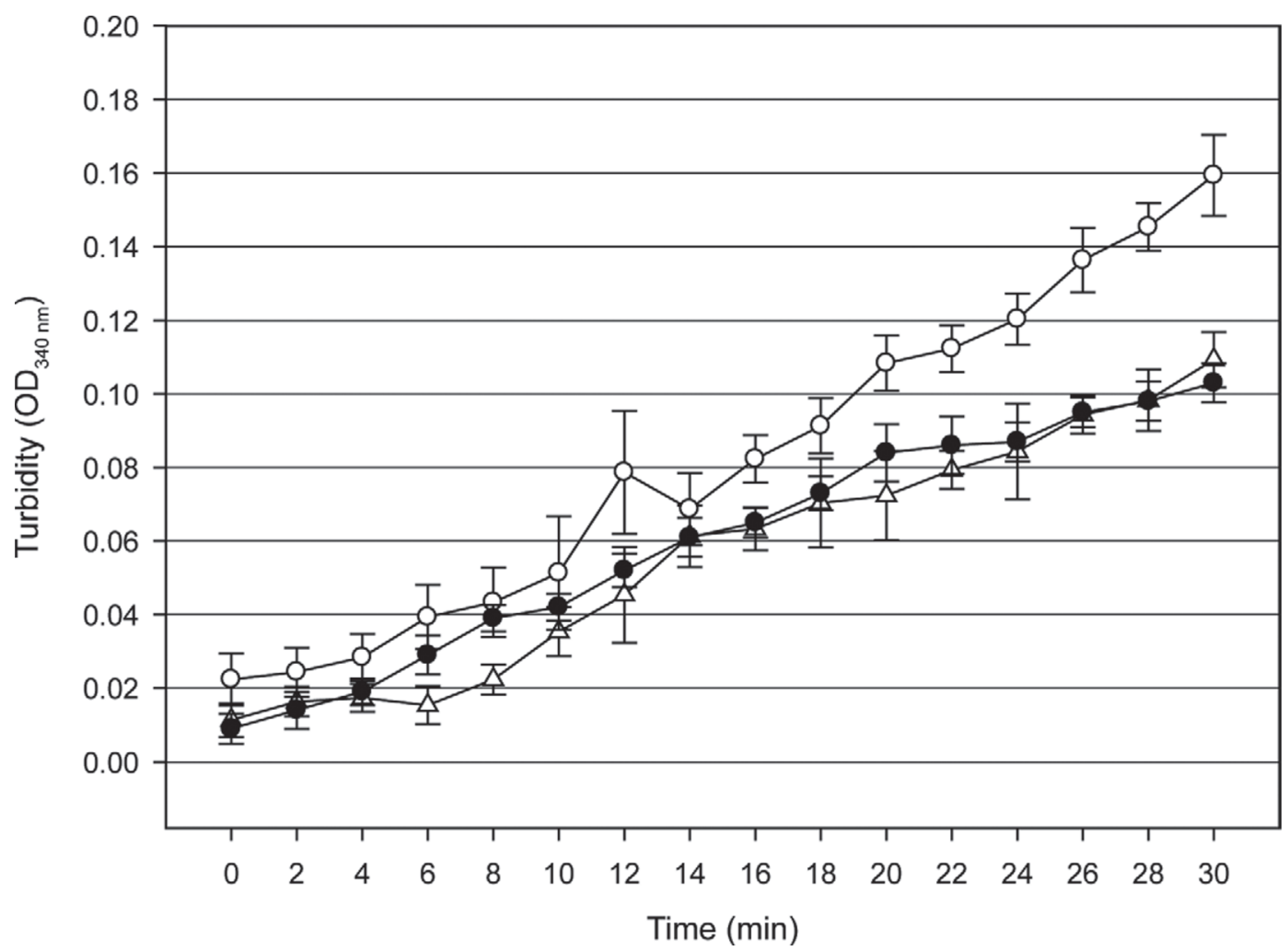

Figure 2. Progress curves observed in assays of $\beta$-oxidation at incubation times: $8 \mathrm{~h}(\bullet), 12 \mathrm{~h}(\bigcirc)$, and $18 \mathrm{~h}(\Delta)$. OD $=$ optical density.

\section{ß-Oxidation Enzyme Activity Assays}

Figure 2 indicates a lag phase in $\beta$-oxidation assays (0-6 min). These results were consistent with Corynebacterium sp. strain 7E1C (Easterby, 1981; Broadway et al., 1992). Assay of $\beta$-oxidation was completed by detecting the NAD+ reduction formed at the third stage of $\beta$-oxidation; therefore, it needed a lag phase to accumulate enough free intermediate concentrations before the next phase of the reaction could be carried out (Broadway et al., 1992). In addition, different growth phases need different amounts of time to accumulate enough free intermediates, so they performed differently in the $\beta$-oxidation analysis (Figure 2).

Table 1. Methyl ketones analysis of fermenting cream

\begin{tabular}{llc}
\hline Item & Ketone & Peak area $^{1}$ \\
\hline Cream & 2-Heptanone & 0.39 \\
& 2-Nonanone & 0.83 \\
& 2-Undecanone & 1.05 \\
Fermented cream & 2-Tridecanone & 0.44 \\
& 2-Heptanone & 0.72 \\
& 2-Nonanone & 1.88 \\
& 2-Undecanone & 1.47 \\
2-Tridecanone & 1.13 \\
\hline
\end{tabular}

${ }^{1}$ Peak area $(\%)=\left(\right.$ compound $_{\text {peak area }} /$ total compound $\left.d_{\text {peak area }}\right)$
The maximum $\beta$-oxidation activity of Lc. lactis in the late-exponential, early-stationary, and late-stationary phases appeared at 8,12 , and $14 \mathrm{~min}$; maximum activity of $\beta$-oxidation was $6.46,7.751$, and $8.203 \mathrm{nmol} /$ mg per minute, respectively. The maximum $\beta$-oxidation activity of Lc. lactis was higher than that of Escherichia coli, which was grown on amino acid and glucose (Weeks et al., 1969), and Staphylococcus carnosus (Engelvin et al., 2000).

\section{Thioesterase Activity Assays}

Thioesterase has been referred to in the literature as deacylase, acyl-CoA hydrolase, acyl-CoA thioester hydrolase, and acyl-CoA thioesterase (Hunt and Alexson, 2002). The acyl-CoA thioesterases are a group of enzymes that catalyze the hydrolysis of acyl-CoA to the FFA and CoA; these enzymes are localized in the cytosol (Hunt and Alexson, 2002) and they regulate concentrations of FA and acyl-CoA due to hydrolysis of acyl-CoA (Veronika et al., 2011).

Thioesterase activity assay curves had no lag period (as shown in Figure 3); the thioesterase activity had the effect of rapidly decreasing the acyl-CoA substrate concentration so that assays were only linear for 3 to 4 min (Broadway et al., 1992). Maximum activity of 


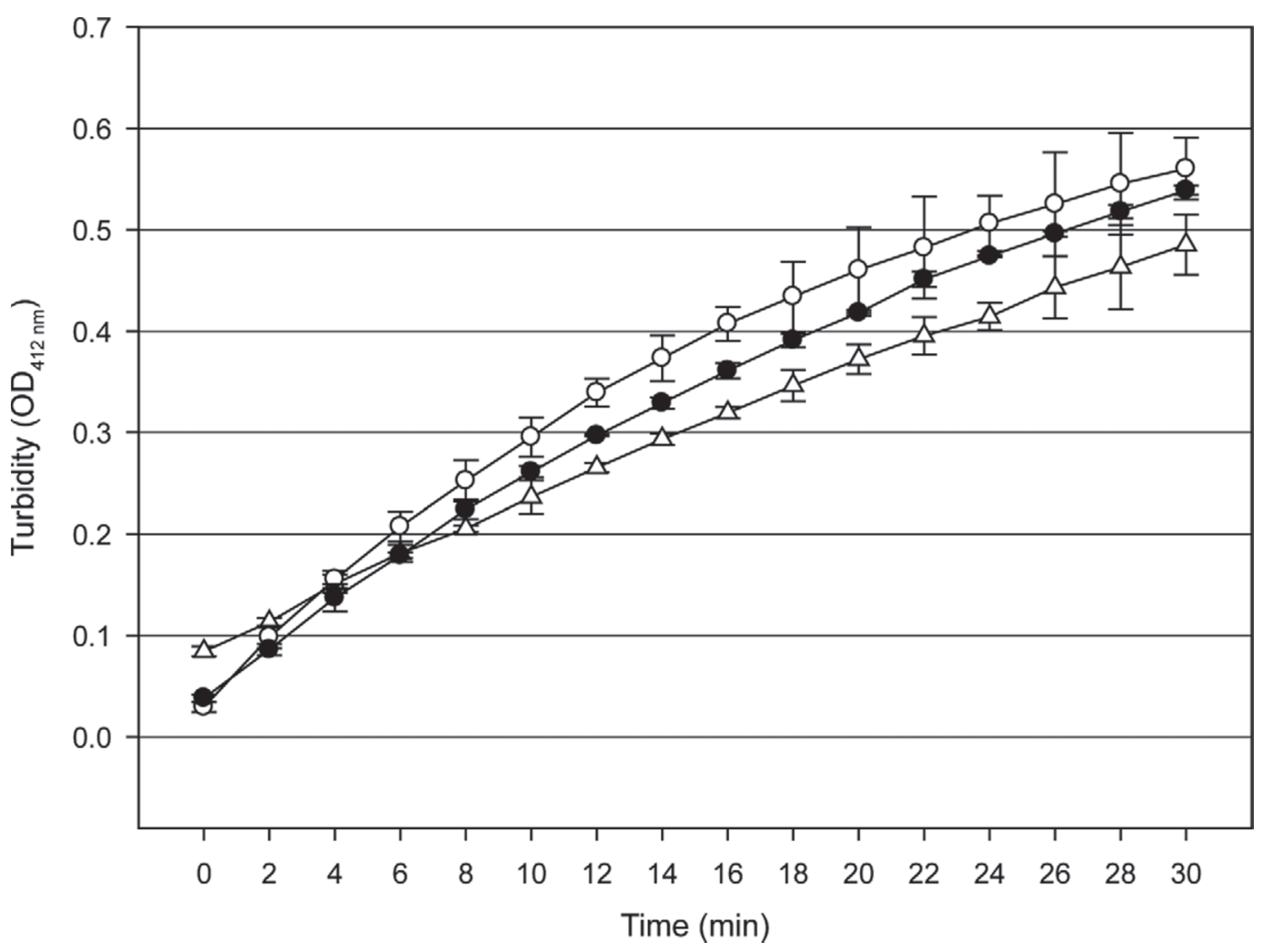

Figure 3. Progress curves observed in assays of thioesterase activity at incubation times: $8 \mathrm{~h}(\bullet), 12 \mathrm{~h}(\bigcirc)$, and $18 \mathrm{~h}(\Delta)$. OD $=$ optical density.

thioesterase with different incubation times $(8,12$, and $18 \mathrm{~h}$ ) were $19.498,27.180$, and 12.800 , respectively. In different incubation times, the maximum activity of thioesterase appears at 2 or 4 min (Figure 4); this is similar to the measurement time of Campylobacter jejuni (0-5 min; Yokoyama et al., 2009). After $4 \mathrm{~min}$, thioesterase activity rapidly decreased; a feedback inhibitor for thioesterase activity might have occurred, as other studies have shown that CoA was a feedback inhibitor for thioesterase separated from mouse liver, pig heart (Hunt and Alexson, 2002), and Escherichia coli (Zhuang et al., 2008).

\section{FFA As Growth Factors on Lc. lactis}

Lactococcus lactis were inhibited by FA from C8:0 to C16:0, and laurate (12:0) had the highest bactericidal effect (Table 2). These results were not completely consistent with the report of Lactobacillus leichmanii, in which growth was inhibited by FA from 8:0 to 12:0 (de Kairúz et al., 1983). The bactericidal effect increased significantly when laurate concentration was increased from 0.25 to $0.5 \mathrm{~m} M$, but increased slowly when laurate concentration was increased from 0.5 to $2 \mathrm{mM}$ (Table $3)$. These results were consistent with the report of $\mathrm{Lac}$ tobacillus delbrueckii (Partanen et al., 2001).

\section{Effect of FFA on the $\beta$-Oxidation System}

The $\beta$-oxidation system of Lc. lactis can be induced (Figure 5) as reported previously: $\beta$-oxidation enzymes of Aspergillus niger were induced by growth on triolein (Baltazar et al., 1999) and those of E. coli were induced by long-chain FA (Campbell et al., 2003). In the current study, decanoic acid (C10:0) and palmitic acid (C16:0) did induce the $\beta$-oxidation system of Lc. lactis (Figure 5), but the results were different. The ability of FA to induce the enzymes of $\beta$-oxidation were a func-

Table 2. Effects of even-numbered FA on the growth of Lactococcus lactis

\begin{tabular}{ll}
\hline Variable & Turbidity value \\
\hline Control & $1.425 \pm 0.015^{\mathrm{a}}$ \\
Hexanoic acid (C6:0) & $1.383 \pm 0.013^{\mathrm{a}}$ \\
Octanoic acid (C8:0) & $1.287 \pm 0.045^{\mathrm{b}}$ \\
Decanoic acid (C10:0) & $0.946 \pm 0.013^{\mathrm{c}}$ \\
Lauric acid (C12:0) & $0.032 \pm 0.008^{\mathrm{f}}$ \\
Myristic acid (C14:0) & $0.359 \pm 0.030^{\mathrm{e}}$ \\
Palmitic acid (C16:0) & $0.767 \pm 0.055^{\mathrm{d}}$ \\
\hline
\end{tabular}

${ }^{\mathrm{a}-\mathrm{f}}$ Values with different superscripts in the same row differ significantly $(P<0.05)$.

${ }^{1}$ Optical density at $600 \mathrm{~nm}$; values expressed as means \pm standard deviation. 
Table 3. Effects of laurate content on the growth of Lactococcus lactis

\begin{tabular}{ll}
\hline Laurate content $(\mathrm{m} M)$ & Turbidity value \\
\hline Control $(0)$ & $1.425 \pm 0.015^{\mathrm{a}}$ \\
0.25 & $0.447 \pm 0.071^{\mathrm{b}}$ \\
0.5 & $0.065 \pm 0.004^{\mathrm{c}}$ \\
0.75 & $0.068 \pm 0.007^{\mathrm{c}}$ \\
1 & $0.071 \pm 0.007^{\mathrm{c}}$ \\
2 & $0.045 \pm 0.021^{\mathrm{c}}$ \\
\hline
\end{tabular}

${ }^{a-c}$ Values with different superscripts in the same row differ significantly $(P<0.05)$.

${ }^{1}$ Optical density at $600 \mathrm{~nm}$.

tion of chain length (Weeks et al., 1969). The ability of Lactobacillus organisms to withstand the toxic effect of FA could be attributed to the presence of FA-oxidation activity in the cell. In this case, as Lc. lactis is grampositive and lacks a lipopolysaccharide layer or outer membrane, FA oxidation appears to be the principal mechanism of resistance (de Kairúz et al., 1983).

\section{Effect of FFA on the Activity of Thioesterase}

Octanoic acid (C8:0) and palmitic acid (C16:0) can induce thioesterase activity of Lc. lactis (Table 4). When we added $1 \mathrm{~m} M$ palmitic acid (C16:0) into M17 broth, the activity of thioesterase increased 5 -fold after
Table 4. Effects of FFA on the activity of thioesterase

\begin{tabular}{lcc}
\hline Fatty acid & $\begin{array}{c}\text { Assay time of } \\
\text { thioesterase (min) }\end{array}$ & Multiple $^{1}$ \\
\hline Octanoic acid (C8:0) & 2 & 1.06 \\
Palmitic acid (C16:0) & 4 & 1.07 \\
& 2 & 5 \\
& 4 & 2.67 \\
\hline
\end{tabular}

${ }^{1}$ Enzyme activity (FFA)/enzyme activity (Control).

2 min; however, little change of octanoic acid (C8:0) was noted. We speculate that long-chain FA can induce thioesterase activity, and chain length may be related to FA-induced thioesterase ability. Of course, these findings require further data for confirmation. After induction, thioesterase activity of Lc. lactis was still less than that of Campylobacter jejuni (Yokoyama et al., 2009) and Saccharomyces cerevisiae (Asteri et al., 2009).

\section{CONCLUSIONS}

Lactococcus lactis had an effective $\beta$-oxidation system and a higher thioesterase activity. The $\beta$-oxidation system and thioesterase activity had been induced by FA, and the different induction abilities were due to

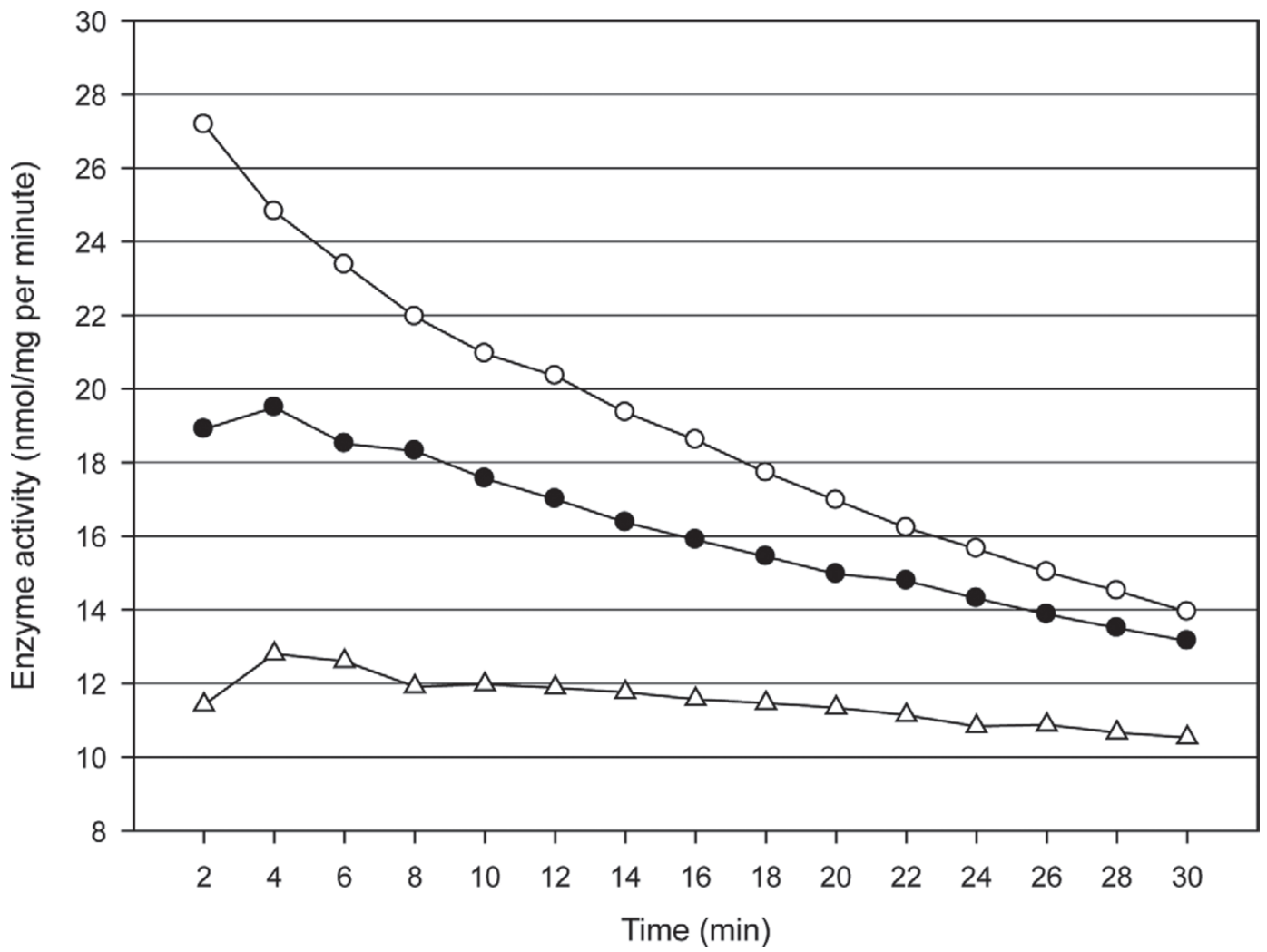

Figure 4. Thioesterase activity at different incubation times: $8 \mathrm{~h}(\bullet), 12 \mathrm{~h}(\bigcirc)$, and $18 \mathrm{~h}(\Delta)$. 


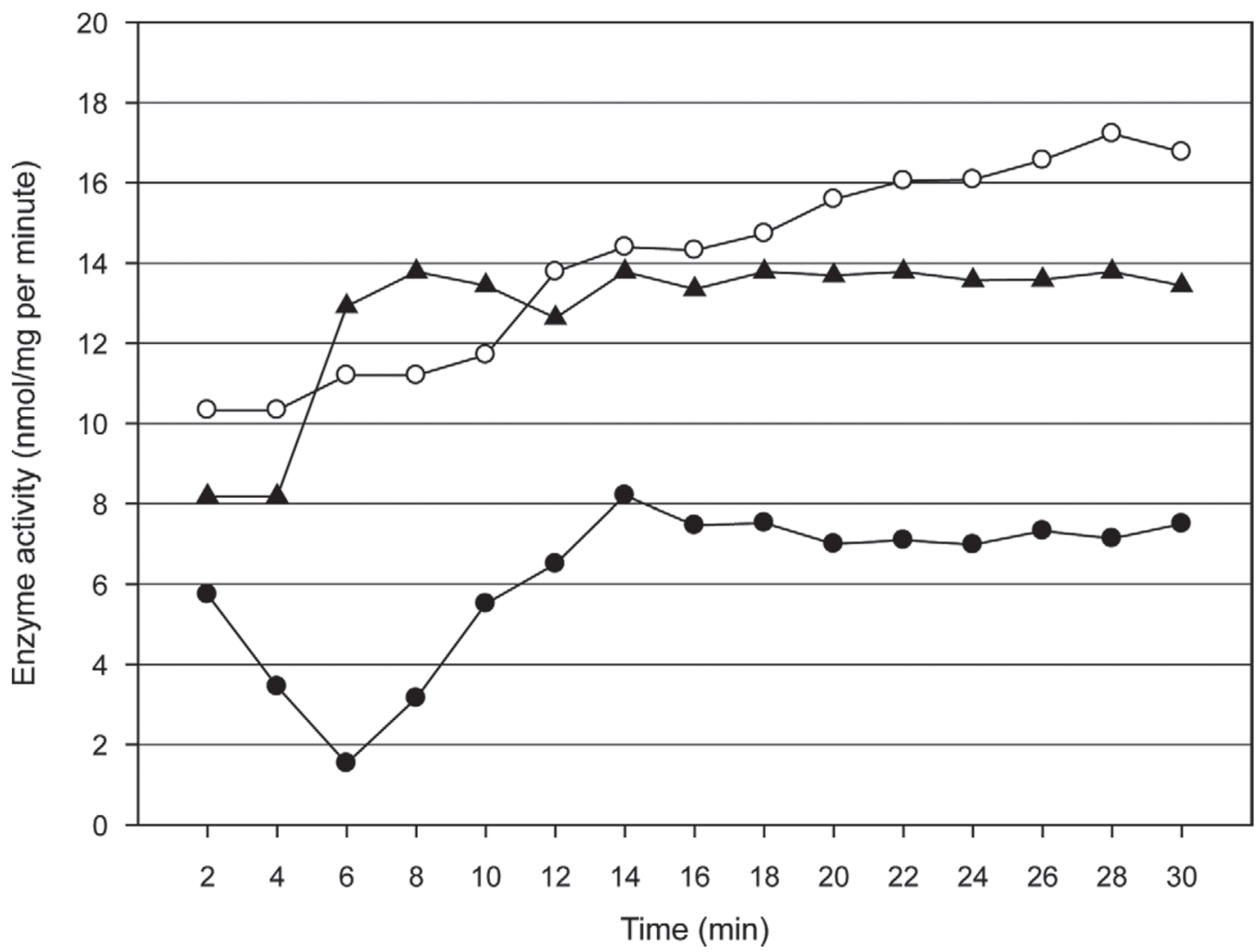

Figure 5. Effects of FFA on the activity of $\beta$-oxidation: decanoic acid (C10:0; $)$, palmitic acid (C16:0; $\mathbf{\Lambda})$, and control without fatty acid

different chain lengths. The results showed that FA (C8:0-C16:0) can significantly inhibit the growth of $L c$. lactis, and laurate (12:0) had the highest bactericidal effect. Thus, we could use FA (such as palmitic acid) to regulate the $\beta$-oxidation and thioesterase enzyme system and subsequently regulate the production of methyl ketone. These findings have important implications for the flavor of the fat-rich food using Lc. lactis as starter, such as cheese, sour cream, and natural butter flavor. These findings also have important quality and economic implications for the food industry. The mechanism of FA on the $\beta$-oxidation system of Lc. lactis and the influence of FA- $\beta$-oxidation on methyl ketones should be studied further.

\section{REFERENCES}

Asteri, I. A., N. Robertson, D. M. Kagkli, P. Andrewes, G. Nychas, T. Coolbear, R. Holland, V. Crow, and E. Tsakalidou. 2009. Technological and flavour potential of cultures isolated from traditional Greek cheeses-A pool of novel species and starters. Int. Dairy J. $19: 595-604$.

Ayala-Hernández, I., A. Hassan, H. D. Goff, R. Mira de Orduña, and M. Corredig. 2008. Production, isolation and characterization of exopolysaccharides produced by Lactococcus lactis ssp. cremoris JFR1 and their interaction with milk proteins: Effect of $\mathrm{pH}$ and media composition. Int. Dairy J. 18:1109-1118.
Baltazar, M. F., F. M. Dickinson, and C. Ratledge. 1999. Oxidation of medium-chain acyl-CoA esters by extracts of Aspergillus niger: Enzymology and characterization of intermediates by HPLC. Microbiology 145:271-278.

Bosset, J. O., and R. Gauch. 1993. Comparison of the volatile flavour compounds of six European II AOC cheeses by using a new dynamic headspace GC-MS method. Int. Dairy J. 3:359-377.

Boumerdassi, H., C. Monnet, M. Desmazeaud, and G. Corrieu. 1997. Isolation and properties of Lactococcus lactis ssp. lactis biovar diacetylactis CNRZ 483 mutants producing diacetyl and acetoin from glucose. Appl. Environ. Microbiol. 63:2293-2299.

Broadway, N. M., F. M. Dickinson, and C. Ratledge. 1992. Long-chain acyl-CoA ester intermediates of beta-oxidation of mono-and dicarboxylic fatty acids by extracts of Corynebacterium sp. strain 7E1C. Biochem. J. 285:117-122.

Campbell, J. W., R. M. Morgan-Kiss, and J. E. Cronan Jr.. 2003. A new Escherichia coli metabolic competency: Growth on fatty acids by a novel anaerobic $\beta$-oxidation pathway. Mol. Microbiol. 47:793-805.

Cárcoba, R., T. Delgado, and A. Rodríguez. 2000. Comparative performance of a mixed strain starter in cow's milk, ewe's milk and mixtures of these milks. Eur. Food Res. Technol. 211:141-146.

Chalier, P., and J. Crouzet. 1998. Methyl ketone production from copra oil by Penicillium roqueforti spores. Food Chem. 63:447-451.

Curioni, P. M. G., and J. O. Bosset. 2002. Key odorants in various cheese types as determined by gas chromatography-olfactometry. Int. Dairy J. 12:959-984.

de Kairúz, M. S. N., G. Oliver, A. A. Pesce de Ruiz Holgado, and R. N. Farías. 1983. Role of $\beta$-oxidation in inhibiting Lactobacillus leichmanii by fatty acids. Curr. Microbiol. 9:105-109.

Delgado, F. J., J. González-Crespo, R. Cava, and R. Ramírez. 2011. Formation of the aroma of a raw goat milk cheese during maturation analysed by SPME-GC-MS. Food Chem. 129:1156-1163. 
Easterby, J. S. 1981. A generalized theory of the transition time for sequential enzyme reactions. Biochem. J. 199:155.

Engelvin, G., G. Feron, C. Perrin, D. Molle, and R. Talon. 2000. Identification of beta-oxidation and thioesterase activities in Staphylococcus carnosus 833 strain. FEMS Microbiol. Lett. 190:115-120.

Feron, G., C. Blin-Perrin, I. Krasniewski, G. v. Mauvais, and J. Lherminier. 2005. Metabolism of fatty acid in yeast: Characterisation of $\beta$-oxidation and ultrastructural changes in the genus Sporidiobolus sp. cultivated on ricinoleic acid methyl ester. FEMS Microbiol. Lett. 250:63-69.

Fox, P. F., T. Singh, and P. McSweeney. 1995. Biogenesis of flavour compounds in cheese. Adv. Exp. Med. Biol. 367:59.

Fox, P. F., and J. M. Wallace. 1997. Formation of flavor compounds in cheese. Adv. Appl. Microbiol. 45:17-85.

Frank, D. C., C. M. Owen, and J. Patterson. 2004. Solid phase microextraction (SPME) combined with gas-chromatography and olfactometry-mass spectrometry for characterization of cheese aroma compounds. Lebenson. Wiss. Technol. 37:139-154.

García-Parra, M. D., B. E. García-Almendárez, L. Guevara-Olvera, R. G. Guevara-González, A. Rodríguez, B. Martínez, J. Domínguez-Domínguez, and C. Regalado. 2011. Effect of sub-inhibitory amounts of nisin and mineral salts on nisin production by Lactococcus lactis UQ2 in skim milk. Food Bioproc. Technol. 4:646-654.

Groguenin, A. 2004. Genetic engineering of the $\beta$-oxidation pathway in the yeast Yarrowia lipolytica to increase the production of aroma compounds. J. Mol. Catal. B Enzym. 28:75-79.

Hannon, J. A., K. N. Kilcawley, M. G. Wilkinson, C. M. Delahunty, and T. P. Beresford. 2007. Flavour precursor development in Cheddar cheese due to lactococcal starters and the presence and lysis of Lactobacillus helveticus. Int. Dairy J. 17:316-327.

Hunt, M. C., and S. E. Alexson. 2002. The role acyl-CoA thioesterases play in mediating intracellular lipid metabolism. Prog. Lipid Res. 41:99-130.

Kabanova, N., A. Kazarjan, I. Stulova, and R. Vilu. 2009. Microcalorimetric study of growth of Lactococcus lactis IL1403 at different glucose concentrations in broth. Thermochim. Acta 496:87-92.

Liu, X., Y.-K. Chung, S.-T. Yang, and A. E. Yousef. 2005. Continuous nisin production in laboratory media and whey permeate by immobilized Lactococcus lactis. Process Biochem. 40:13-24.

Marilley, L. 2004. Flavours of cheese products: Metabolic pathways, analytical tools and identification of producing strains. Int. J. Food Microbiol. 90:139-159.
Nagayasu, M., A. K. Wardani, K. Nagahisa, H. Shimizu, and S. Shioya 2007. Analysis of hemin effect on lactate reduction in Lactococcus lactis. J. Biosci. Bioeng. 103:529-534.

O'Connell, M., S. Henry, and L. Shapiro. 1986. Fatty acid degradation in Caulobacter crescentus. J. Bacteriol. 168:49-54.

Partanen, L., N. Marttinen, and T. Alatossava. 2001. Fats and fatty acids as growth factors for Lactobacillus delbrueckii. Syst. Appl. Microbiol. 24:500-506.

Samaržija, D., N. Antunac, and J. L. Havranek. 2001. Taxonomy, physiology and growth of Lactococcus lactis: A review. Mljekarstvo 51:35-48.

Sirén, N., K. Salonen, M. Leisola, and A. Nyyssölä. 2009. A new salt inducible expression system for Lactococcus lactis. Biochem. Eng. J. $48: 132-135$.

Town, G. I., P. Fraser, S. Graham, W. McSweeney, K. Brockway, and R. Kirk. 2000. Establishment of a smoking cessation programme in primary and secondary care in Canterbury. N. Z. Med. J. 113:117-119.

Urbach, G. 1997. The flavour of milk and dairy products: II. Cheese: Contribution of volatile compounds. Int. J. Dairy Technol. 50:7989.

Valbuena, E., J. Barreiro, E. Sánchez, G. Castro, W. Bríñez, and A. Tovar. 2005. Growth kinetics models applied to Lactococcus lactis ssp. lactis in milk. Rev. Cien. 15:464.

Veronika, P., P. Hana, P. Jiri, B. Hana, S. Jana, and H. Klara. 2011. Combined exposure of Japanese quails to cyanotoxins, Newcastle virus and lead: Oxidative stress responses. Ecotoxicol. Environ. Saf. 74:2082-2090. http://dx.doi.org/10.1016/j.ecoenv.2011.07.014

Weeks, G., M. Shapiro, R. Burns, and S. J. Wakil. 1969. Control of fatty acid metabolism I. Induction of the enzymes of fatty acid oxidation in Escherichia coli. J. Bacteriol. 97:827-836.

Yokoyama, T., K.-J. Choi, A. M. Bosch, and H.-J. Yeo. 2009. Structure and function of a Campylobacter jejuni thioesterase Cj0915, a hexameric hot dog fold enzyme. Biochim. Biophys. Acta Prot. Proteom . 1794:1073-1081.

Zhuang, Z., F. Song, H. Zhao, L. Li, J. Cao, E. Eisenstein, O. Herzberg, and D. Dunaway-Mariano. 2008. Divergence of function in the hot dog fold enzyme superfamily: The bacterial thioesterase YciA. Biochemistry 47:2789-2796. 